\title{
Management of Fishing Operational on Lift Net in Lekok Waters, Pasuruan Regency, East Java
}

\author{
Dimas Satrya ${ }^{1}$ \\ ${ }^{1}$ Agribusiness Department, Agriculture Faculty of Jember University, Indonesia
}

\begin{abstract}
Indonesia is an archipelago country, catching fish is one of the sectors that is highly evolved in Indonesia. One of the waters in Indonesia which has great fishery potential is Pasuruan Regency in East Java. Lift net is a fishing tool that is still widely used by small-scale fishermen in Indonesia, formed rectangular which was operable in coastal waters at night by using light fishing. The purposes of this article are to investigate how to operate a lift net and to explore deeper about the management of lift net operation in Lekok Waters, Pasuruan Regency. Data collection was done by using observation, interview, active participation and documentation. This research discuss about boat and the equipment, catcher tool components, location, length time of trip, procedures of fishing, types of fish, tools maintenance and business management. Based on the analysis of Revenue Cost Ratio (R/C Ratio) proved R/C ratio is > 1 , then the effort of catching fish by using lift net in Lekok Pasuruan is profitable. The value of BEP in units of the unit catchment is $1,278 \mathrm{~kg}$, and the values BEP in-unit rupiah is Rp.9,064,516.
\end{abstract}

\section{INTRODUCTION}

Indonesia is an archipelago country which consists of 17,000 over islands to the beach line along 81,000 $\mathrm{km}$, so catching fish is one of the sectors that is highly evolved in Indonesia. Indonesia consists of $2 / 3$ of its territory is the ocean and the abundant amount of fish in the Indonesian sea in a year this country has the potential sustainable fisheries products (Maximum Sustainable Yield) of marine fisheries reaching 6,4 million tons [1].

One of the waters in Indonesia that has great potential fishery is Pasuruan, East Java. The sea in Pasuruan stretches along $\pm 48 \mathrm{~km}$ ranging from the Nguling to Bangil sub-district, with a wide area of the sea reaches approximately $208.35 \mathrm{~km}^{2}$ with potential for sustainable (MSY) $\pm 27,000$ tons per year. The medium to exploit the potential of marine fisheries has also been equipped with a Fish Landing Center (PPI) which is placed in Lekok District. Pasuruan district has three centers catching fish which is located in Kraton, Lekok, and Nguling district with 12,059 households of fishermen and 2,281 fleet arrest. Lekok district is the central largest of catching fish with 5,723 households fishermen and 1,621 fleets catching fish [2]. A group of fishermen in Lekok Pasuruan mostly use fishing gear called a chart step by using the pumped lamp as a tool to help to collect fish that are still using the pumped lamp with materials fuel oil land [3].

Lift net is a traditional fishing gear in the form of bamboo in a square form which is attached in the seabed and stands firmly above the water, where in the middle of the building is installed net and operated by using light (light fishing) [4]. Silitonga et al state that lift net arrangement of bamboo-shaped in square were plugged in the base water that stands solid on top of the water, where in the middle of the building is fitted nets [5]. Lift net is passive and operated using light bulbs to collect fish. Lift net is one kind of fishing gear which is quite widely used in Indonesia. The large number of lift net usage cannot be separated from regional development, technological ease, low investment level, and one-day fishing method of catching. Stationary lift net is a lift net mounted by placing the body frame into the water, so the position of the lift net can be planted only once and can't move during the fishing season. Fishing operation of the stationary lift net is done at night. Most use light coming from a petromax lamp, although some use electric lights [6].

Generally, the operation of lift net tools is only at night the (light fishing), especially at the time of the dark moon by using light as a tool to help to catch fish, this case is due to the catching chart target is positive phototaxy fish [7]. The operation principles of lift net is to utilize light as a helping tool that is used on the night, it is because fish has positive phototaxy. Positive phototaxy is the movement or lack of movement, in response to light [8]. The benefit of light while catching using lift net is to collect fish in certain catchable area, after that the fish is collected with a net. It means that the net is passive that the light attracting fish to the net. The components of lift net is net house, the structure, the frame net, the roller, the ropes, the lamps, and the spoon. Lift net house is a house made on the top of lift net for fishermen's resting place.

According to Dewanti et al, the population of grown fish is fish that likes to live in groups and move quickly simultaneously and together. But, the population of small fish is likely to still be in the surrounding spawning habitat, because it has not been able to move quickly to follow the population of grown fish [9]. By their nature fish are divided into two, namely positive phototaxy where fish are attracted to light stimulation and negative phototaxy is the fish that are not attracted to light stimulation. The use of the color of the lights on the lift net certainly will affect the fish results of catches were obtained [10]. Research conducted by Aswirani 
[11], showed that the results of catches on the lift net using technology tools LED lamp indicates more substantial than using Neon lamp. However, the weaknesses of operating lift net using the lamp is while the fish are located around the lift net is not too much, then the fish that will gather after the lamp is turned on also not be much [12].

The fish that are generally caught with lift net are small types of pelagic clustered fish located on the surface, for example, anchovy (Stolephorus sp.), sardine (Sardinella fimbriata), mackerel (Rastrellinger sp.), Squid (Loligo sp.), Kite (Decapterus macrosoma), pony fish (Leiognathus equulus), tootpony (Gaza minuta) and yellowstripe scad (Selaroides leptolepis).

Lift net fishery is a traditional tool to catch which the existence is still maintained by the community of fishermen because it has several advantages. First, it's technically easy to do. Second, the investment is affordable by the community. Third, it is the people's tools that have been used by people in coastal areas and around small islands for generations. Fourth, the catch is always there even though sometimes the amount is small. Fifth, it absorbs the working families. Sixth, the technology is very simple [13].

The lift net in the operating stage has caused various problems, especially those related to voyage lines. The operation which settled with the stick of bamboo in the beach in the amount that is quite a lot, so it can block the flow of the traffic ship. But on the other lift net is one of the alternative technology catching up with investments that are relatively cheap compared to the type of tool to catch the other [14].

Based on the description above, it would have been better know the management of the lift net equipment technically and in fishing activities. Therefore, it is necessary to conduct a research on the management of fishing operations on lift net in Lekok Water, Pasuruan Regency. The purposes of this article are:

- To investigate how to operate a lift net in Lekok Water, Pasuruan Regency.

- To explore deeper about the management of lift net operation in Lekok Waters, Pasuruan Regency.

\section{METHODOLOGY}

Sugiyono said that research methodology is a scientific way to obtain data with specific purposes and uses [15]. Source of data in the study was the subject of where the data can be obtained. If the researcher uses a questionnaire or interview in gathering data, the source of the data is called a respondent, that is the person who responds or answers the researcher's questions, both written and oral questions [16].

Data obtained in this study include primary and secondary data.

- Primary data is a source of data obtained directly from the original source (not through intermediary media). Primary data can be either subject (person) opinions individually or in groups, the results of observations of an object (physical), event or activity, and test results [17]. While Sanusi [18], revealed that the primary data is the data that is the first time recorded and collected by researcher. Accordingly, this primary data is obtained directly from the recording of observations, interviews, active participation, and documentation about the things studied, namely the specifications of the ship, fishing gear that will be used for the fishing process and catch.

- Secondary data is data obtained indirectly. Secondary data is usually published by certain institutions [19]. While Sanusi [18], revealed that the secondary data is data that is already available and collected by the other. Secondary data is data obtained beyond the research subject. It is also called second hand data. It is usually in the form of available documentation data or report data.

Data collection on this article is described bellow:

- Observation is carried out through the sense of vision, smell, hearing, feeling and taste (direct observation). The observation method used in this research was by taking data directly in the field, that was to see and to observe directly the operation method of lift net and the catch [16]. Observation, according Sugiyono [15], is a technique of collecting the data with observations used when research regarding the behavior of humans, the process of labor, the symptoms of nature and when respondents were observed not too big.

- Interview is the process of obtaining information for the purpose of research by way of question and answer, while face-to-face between the interview or the interviewer by the answering or the respondent by using an instrument that is called an guidance interview [20].

- The active participation in observation means the researcher involved do anything that is done by the speakers, but not fully complete yet [15]. The nature of participatory observation is researcher involved with the daily people activities which are being observed or used as a source of data research.

- The documentation process is to find data on things or variables in the form of notes, transcripts, books, newspapers, magazines, inscriptions, minutes, agendas, and so on. In using this method the researcher holds a check-list to find the variables that have been determined [16]. While according Indriantoro and Supomo [21], that the documentary of data are types of data from the research are in the form of invoices, journals, letters, the results of the meeting, memo, or in the form of a report program.

\section{RESULTS AND DISCUSSION}

\subsection{Boat and The Equipment}

The lift net boat is simpler with other types of boats. This is because it is only used for transportation of fishermen toward the lift net and to transport fish obtained from the catches. The driving machine used in $\mathrm{KM}$. EVI is a Yanmar engine with $16 \mathrm{PK}$ engine power. This machine used diesel fuel. The drive motor system 
located outside could be easily lifted to avoid danger when the water condition was shallow (receding).

Catching fish using lift net was done at night. The lamp was well utilized to light the water that could gather in certain catchable areas. Lights that were used LED (Light Emitting Diode) lights with 50 watts of power. Fishermen of lift net in Lekok Water turned on the lights used the energy from generator sets or local fishermen generators. Output power was 850 watt - 950 watts and the fuel used premium gasoline. Cables and sockets were used as a connector / channel of energy released by the generator to turn on the light so that it can shine the surface above the water. Fishermen used slap ropes to tie the hanging lamp on the top of the lift net. The slap rope used was made of polyethylene (PE) with a diameter of $6 \mathrm{~mm}$. Besides that, it was used as a binder of bamboo - a bamboo forming an step chart. Ballast used by fishermen was made of orderly stones arrangement. Tied by using raffia straps and tied it up using a slap rope. The ballast function was to stabilize the hanging lamp above the surface of the water so it will not move whenever blown by the wind.

Fishermen called the catch basket. It is basket brought from the land every time you want to fish that is used to collect the fish. Fishermen of lift net usually carry 1-3 baskets, if in fish season 5-8 baskets. Shovel was used to put the fish on the net into the catch basket. This shovel has $3.5 \mathrm{~m}$ length with a diameter of mouth $30 \mathrm{~cm}$, and a net height $60 \mathrm{~cm}$ with a mesh size of $1 \mathrm{~cm}$ made of polyethylene.

\subsection{Catcher Tool Components}

The structure of lift net was made from bamboo and wood connected surrounding the net functioning as the main leg to support the net. The size of lift net depends on the capacity the fisherman's desires. Besides that, the support can be a place to hang nets, a place to do set, a place to hang lights, a roller seat, and other activities (repairing net, sorting the catches, fishing).

Rectangular frame made of bamboo with a length of 9-10 $\mathrm{m}$ with a diameter of $7 \mathrm{~cm}$. The bamboo was connected one to each other with the width of the net mouth and the frame. The net frame serves as a place to tie nets, weights, and ropes that are connected by roller nets. At each corner of the net frame is tied to a rock, as well as the side of the net frame tied with $3(7-10 \mathrm{~kg})$ stones. The net on net lift is a net upside down curtain and made of net material (polypropylene). Net mesh size $3 \mathrm{~mm}$, and local fishermen called it waring net because the mesh is very small size with a size of $15 \times 15$ meters. The edges of the net was made of polyethylene (PE). The net is tied to the net frame with the desired length, width and depth.

Based on its function, the roller on the lift net consists of 2 (two) types, namely: 1) A roller for a net frame, to take the net frame down or up when setting and hauling. This roller is mounted across the left and right sides of the center of the frame. The length of the roller rope is between 15-25 meters with diameter rope of $1 \mathrm{~cm}$ made of polyethylene (PE). Along the roller was made a handle that was to rotate the roller. 2) Ballast rollers, meant to pull up and down the ballast. $\pm 20 \mathrm{~kg}$ ballast meant to hold the net frame when the tide was strong so that the net frame stayed under the frame. It consisted of 4 pieces of ballast rollers, 2 pieces in front and 2 pieces in the back. The roller was made of polyethylene (PE) with a diameter of $1 \mathrm{~cm}$ and a length of $25 \mathrm{~m}$.

The lift net house was placed in the center of the lift net and the size was adjusted according to the lift net. This house used as a resting place, lights and switch panels, generator sets, and other equipment.

\subsection{Location}

Lift net in Lekok Water, Pasuruan was a passive fishing gear. Therefore, the fishing area was determined in the early of the making of the lift net. The location of catching in Lekok Water generally consisted of mud substrate. The operation of lift net fishing gear was generally carried out in Lekok Water in various depth of $15-25 \mathrm{~m}$. The farther the location of the fishing gear placement, the less amount of lift net. The operation of lift net fishing the Lekok Water was carried out at night.

\subsection{Length Time of Trip}

Fishermen of lift net in Lekok Water had done the fishing 6 times at night for a week, fishermen usually took a day off on full moon period and Friday because at that time the catch tends to be less than the catch in normal months. They usually left at 6:00 p.m. and went back home the next day at 5:00 p.m.

\subsection{Procedures of Fishing}

Preparation carried out before the setting was to turn on and check generator fuel whether all the equipment for fishing process were ready to use. After that, tying up the cable and the tools which was the lamp in the position that should be placed in a place usually tied.

The setting starts at dusk around 7:00 p.m. After all the nets been tied to the frame of the chart, then the light turned on. Before taking the net frame down, the ballast roller as a net barrier from the current was being shaken along with the net was lowered so that the side web frame was evenly down and there was no one higher or lower. Two until three hours after the light turned on, a turning off the lamp continued. Lightning was done in stages to avoid fish being surprised and fish getting closer to the middle of the net. The first lamp being turned off was the lamp on the edge of the frame. Usually fishermen can set as much as 2-3 times, 2 times if not in the fish season and 3 times or more in the fish season. One time setting took $\pm 3-3.5$ hours, depending on how much fish gather in a particular area. If a lot of fish gathered in a certain area out of usual hour, then the hauling process was conducted.

Hauling or withdrawal is an activity to get fish after the setting process is done. The numbers of fishermen in a fishing gear were 3 people, including sea lanes. The net 
withdrawal began after the Sealord has signaled that the net must be immediately withdrawn. The net pulling was carried out after the skipper observed visually a group of fish found under the frame. The web roller roll was done quickly so that the fish hordes in the catchable area did not escape. The time needed to pull up the net to the surface of the water depending on the speed of the current and the depth of the frame of the net, generally the length of the drawing was around 5 minutes. Fishermen were very influential during the hauling process. It could not be arbitrary people who rotated rollers, meanwhile experienced fishermen who were in charge of turning the roller. The next process was to herd the fish by tying the net to the sides of lift net frame functioning as a bag after the frame is stretched to the lift net structure. If the fish had been collected, the fish was lifted onto the net lift by using a shovel by sorting. The fish grouped into its type in baskets.

\subsection{Types of Fish}

Target fish is fish that is targeted by fishermen that they have marketing values such as: yellowstripe scad (Selaroides leptolepis), female mackerel (Rastrellinger brachyoma), male mackerel (Rastrellinger kanagurta), squid (Loligo sp.), toothpony (Gaza minuta), ponyfish (Leiognathus equulus), senuk (Sphyraena jello), sardine (Sardinella fimbriata), kite (Decapterus macrosoma) and anchovy (Stolephorus sp.). Lift net fishermen divides it into two categories of non-target fish, namely bycatch fish and discard fish.

Bycatch fish is fish that is accidentally caught but still has a selling price in the market and also have a fairly high price. Discard fish is fish that is accidentally caught but do not have a selling price in the market and also have no economic value, due to being toxic, stinging and dangerous if it is consumed. Fish trap bycatch such as spotted grouper (Epinephelus cyanopodus), layur (Lepturacanthus savala), red snapper (Lutjanus gibbus), lime (Acanthopagrus berda), octopus (Octopus sp.), Julung - julung (Dermogenys sp.), Brown snapper (Lutjanus fulvus) and red curry (Pristipomoides sp.). Discard fish such as: jellyfish (Aurelia aurita), kentang-kentang (Scatophagus argus), striped broth (Gymnothorax enigmaticus), adjoining fish (Pseudorhombus arsius) and pakol (Balistapus undulatus).

\subsection{Tools Maintenance}

Maintenance of lift net is worked on by fishermen who have boats. As well as the maintenance of the engine, it is done every time sailing or just fast checking whenever it is in good condition. The maintenance of propellers to get rid residual materials done in time going to the lift net has no problem.

Fishing gear is very crucial in fishing, so maintenance must be done to make it long last and not inhibit the fishing process. Maintenance of lift net done right after hauling process is completed, including in the binding of the net to the frame and when it is damaged or the net is torn. This is done to avoid further damage and it can be repaired immediately.

\subsection{Business Management}

Initial investment capital is capital that must be spent at the beginning of the business. In fishing businesses using lift net, the capital includes boats, machinery, and fishing gear (lift net) it can be seen in table 1 .

Working capital is capital that must be spent relating to fixed and non-fixed cost according to the size of the production and can be used for a considerable period of time, this is presented in table 2.

\begin{tabular}{|c|c|}
\hline Cost & Total (Rp) \\
\hline $\begin{array}{l}\text { Fixed Cost } \\
\text { 1. Depreciation }\end{array}$ & $5.620 .000,-$ \\
\hline $\begin{array}{l}\text { Variable Cost } \\
\text { 1. Fuel Oil } \\
\text { 2. Supplies (3 fishermen) }\end{array}$ & $\begin{array}{l}16.536 .000,- \\
23.400 .000,-\end{array}$ \\
\hline Total & 45.556.000,- \\
\hline
\end{tabular}

Trip expense is a cost that is spent relating to fishing process. The cost incurred by the fishermen for lift net in Tambak Lekok Village for a day is Rp.128,000,-. This fee consists of purchasing fuel oil (diesel) as much as 3 liters (price per liter of Rp.6,000,-) and fuel oil as much as 5 liters (price per liter of Rp.7,000,-) so the total is Rp.53,000,-. Other costs needed are the cost of sailing for 3 people which includes the purchase of cigarettes, rice, drinking water and snacks of Rp.75,000,-. Lift net fishermen trip 6 times a week and on Friday, so the trip costs in 1 year period ( 1 month counted 26 days) is Rp.39,963,000,-.

The dry season, it occurs approximately 5 months between May and September. The fish caught by fishermen ranges from Rp.31,200,000,-. The result was reduced as much Rp.16,640,000,- as catch operational costs. Accordingly, fishermen only receive Rp.14,560,000,-. The transition season approximately 4 months between October and January that the fish caught by fishermen ranges from Rp.36,400,000,-. The result was reduced as much Rp.13,312,000,- as catch operational costs. Thus, fishermen only receive Rp.23,088,000,-.

Table 1. Initial Investment Capital

\begin{tabular}{|l|r|r|r|r|r|}
\hline \multicolumn{1}{|c|}{ Investment } & \multicolumn{1}{c|}{$\begin{array}{c}\text { Price } \\
\text { (Rp) }\end{array}$} & $\begin{array}{c}\text { Amount } \\
\text { (Unit) }\end{array}$ & $\begin{array}{l}\text { Total } \\
\text { (Rp) }\end{array}$ & $\begin{array}{c}\text { Econimic Life } \\
\text { (Year) }\end{array}$ & $\begin{array}{c}\text { Depreciated Cost } \\
\text { (Rp) }\end{array}$ \\
\hline Boat (Second Hand) & $6.100 .000,-$ & 1 & $6.100 .000,-$ & 5 & $1.220 .000,-$ \\
\hline Machines & $6.500 .000,-$ & 1 & $6.500 .000,-$ & 10 & $650.000,-$ \\
\hline Fishing Gear & & & & & \\
1. Bamboo & $20.000,-$ & 250 & $5.000 .000,-$ & 2 & $2.500 .000,-$ \\
2. Net and rope & $1.000 .000,-$ & 1 & $1.000 .000,-$ & 2 & $500.000,-$ \\
\hline
\end{tabular}




\begin{tabular}{|l|r|r|r|r|r|}
\hline 3. Fishing equipment & $1.500 .000,-$ & 1 & $1.500 .000,-$ & 2 & $750.000,-$ \\
\hline Total Investment (Rp) & & $\mathbf{2 0 . 1 0 0 . 0 0 0 , -}$ & $\mathbf{5 . 6 2 0 . 0 0 0 , -}$ \\
\hline
\end{tabular}

The peak season occurs approximately 3 months between February and April. The fish caught by fishermen ranges from Rp.37,440,000,-. The result was reduced by Rp.9,984,000,- as catch operational costs so fishermen only receive Rp.27,456,000,--

Fishing business using lift net considered beneficial because the catch is promising. With the gross proceeds of Rp.105,040,000,- and the net is Rp.59,484,000,- per year.

Analysis of Revenue Cost Ratio (R/C Ratio) is a balance or comparison between total revenue (TR) and total cost (TC). This analysis aims to watch in short term whether a business has earned profit or not. The criteria is if the $\mathrm{R} / \mathrm{C}$ ratio $>1$, then the business produces profits, if the $\mathrm{R} / \mathrm{C}$ ratio $=1$, then the business does not profit or loss (break-even) and if the $\mathrm{R} / \mathrm{C}$ ratio $<1$ then the business experiences a loss.

$$
\begin{gathered}
\frac{R}{C} \text { ratio }=\frac{\mathrm{TR}}{\mathrm{TC}} \\
\frac{R}{C} \text { ratio }=\frac{\text { Rp.105.040.000,- }}{\text { Rp.45.556.000,- }} \\
\frac{R}{C} \text { ratio }=2,30
\end{gathered}
$$

Because the value of the $\mathrm{R} / \mathrm{C}$ ratio is $>1$, the fishing business using lift net is advantageous.

Break-even analysis is a technique to study the relationship between fixed costs, variable costs, profits and volume of activities. The sales volume where the income (revenue) is exactly the same as the total cost, so the company does not get a profit or loss called a "breakeven point". One way to determine the break-even point is to make break-even picture, this case explained in figure 1 below.

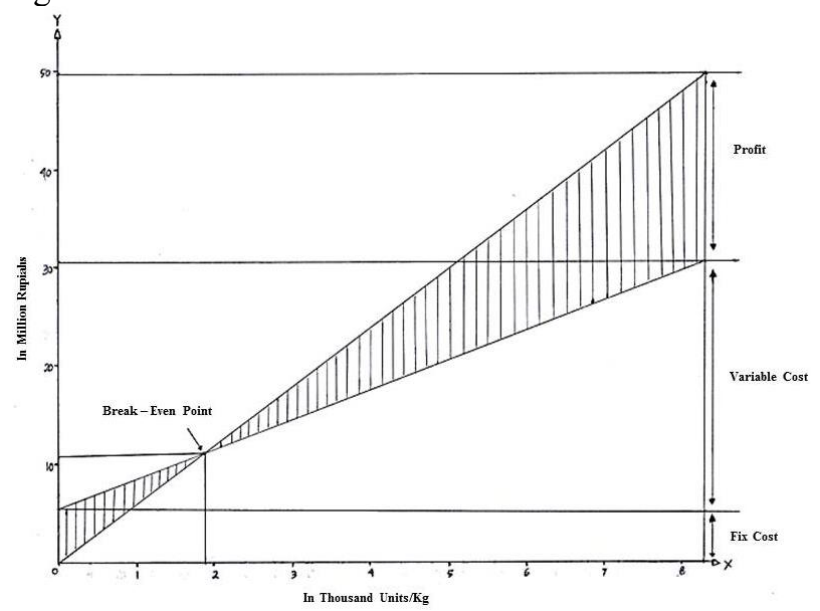

Fig 1. Break-even Point (BEP).

Break-even Point in unit $\mathrm{kg}$ can be seen in the following calculation.

$$
\begin{gathered}
B E P \text { (unit) }=\frac{\mathrm{FC}}{\mathrm{P}-\mathrm{V}} \\
B E P(\text { unit })=\frac{\mathrm{Rp} .5 .620 .000,-}{(\text { Rp.7.000,-) }-(2603,38 \mathrm{Kg})} \\
B E P \text { (unit) }=\frac{\mathrm{Rp} .5 .620 .000,-}{4396,62 \mathrm{Kg}} \\
B E P \text { (unit) }=1278,25 \mathrm{Kg} \\
B E P \text { (unit) }=1278 \mathrm{Kg}
\end{gathered}
$$

While, Break-even Point in rupiahs can be seen in the following calculation.

$$
\begin{gathered}
\text { BEP }(\text { rupiah })=\frac{\mathrm{FC}}{1-\frac{\mathrm{VC}}{\mathrm{S}}} \\
B E P(\text { rupiah })=\frac{\mathrm{Rp} \cdot 5 \cdot 620.000,-}{1-\frac{\mathrm{Rp} \cdot 39.936 .000,-}{\mathrm{Rp} \cdot 105.040 .000,-}} \\
B E P(\text { rupiah })=\frac{\text { Rp.5.620.000,- }}{1-0,38} \\
B E P(\text { rupiah })=\frac{\text { Rp.5.620.000,- }}{0,62} \\
B E P(\text { rupiah })=\text { Rp. } 9.064 .516,-
\end{gathered}
$$

\section{CONCLUSIONS AND SUGGESTIONS}

\subsection{Conclusion}

The conclusions drawn from the research are as follows:

- Equipment that were carried during the operation of lift net fishing were; 1) Boat; 2) arresting aids; 3) Generator set; 4) Cable and socket; 5) Slap rope; 6) Ballast; 7) Catch basket; 8) shovel.

- The catch category was divided into 2, namely: 1) Target fish; 2) Non - target fish by catch and discard.

- Analysis of Revenue Cost Ratio (R/C Ratio) proves $\mathrm{R} / \mathrm{C}$ ratio $>1$ then fishing business using fishing gear was advantageous.

- BEP value (unit) results from the calculation of data between fixed costs, variable costs, profits and activity volume was $1,278 \mathrm{Kg}$. While, the value of BEP (rupiahs) results from the calculation of data between fixed costs, variable costs, profits and volume of activities was Rp.9,064,516,--

\section{REFERENCES}

1. Masjamsir Mulyawan, Yuli Andriani. PPWCL. Jurnal Perikanan Kelautan. VI (2) . 116-124 (2015)

2. Sukandar Fuad, Alfan Jauhari. PLBW. Jurnal Kelautan. 9 (1). 7-11 (2016)

3. Sukandar Fuad. PLCBW. Journal of Innovation and Applied Technology. 1(2) 101-105 (2015)

4. Khumaera, NI. AoOLoLO. IOP Conf. Series: Earth and Environmental Science (2019)

5. Monica Febriana Silitonga, Hartoko Agus Pramonowibowo. ASBdHT. Journal of Fisheries Resources Utilization Management and Technology. 3(2). 77-84 (2014)

6. Hapsari, Trisnani D. BPoBLN. 3rd International Conference on Tropical and Coastal Region Eco Development (2018)

7. B. B Jayanto, A. Rosyid Asriyanto, H. Boesono. PAR. PENA. 26(2). 119-133 (2014)

8. Nguyen, Khanh Q. AliCI. Reviews in Fisheries Science \& Aquaculture. 27 (1). 106-126 (2018)

9. Dewanti, Ghofar A, Saputra SW. BABIT. Diponegoro Journal of Maquares. 3(4). 102-111 (2014)

10. Faisal Aliyubi, Herry Boesono, Indradi Setiyanto. APHTBWL. Journal of Fisheries Resources 
Utilization Management and Technology. 4(2). 93$101(2015)$

11. Vera Aswirani. PHTBT. Skripsi Program Studi Pemanfaatan Sumberdaya Perikanan Universitas Hasanuddin (2018)

12. Bogi Budi Jayasanto et al. PACtHT. Jurnal Saintek Perikanan. 11(2). 134-139 (2016)

13. Rachmaniar, Mustari S. Lamada. PTOPJ. Jurnal Pendidikan Teknologi Pertanian. 4. 112 -117 (2018)

14. Warda Susaniati, Alfa Nelwan, Muh Kurnia. PDPIBT. Jurnal Akuatika. IV(1). 68-79 (2013)

15. Sugiyono. MPP. Penerbit CV. Alfabeta: Bandung (2015)
16. Suharsimi Arikunto. PP. Jakarta: Rineka Cipata (2013)

17. Naga. DPdDS. http://DATA/SEKUNDER/DAN DATA/PRIMER/Nagabiru.html. Access on June 14th 2019.

18. Anwar Sanusi. MPB. Jakarta: Salemba Empat (2014)

19. Kertati, Indra. AKKS. Riptek. 7 (1). 27-38 (2013)

20. Mohammad Nazir. MP. Jakarta: Ghalia Indonesia (2014)

21. Nur Indriantoro, Supomo. MPB. Yogyakarta: BPFE (2014) 